DOI: $10.5277 /$ epe 160410

\author{
TOMASZ SUPONIK ${ }^{1}$
}

\title{
STUDY OF PRECIPITATES FORMED ON IRON REACTORS FOLLOWING THE REMOVAL OF COPPER FROM WATER
}

\begin{abstract}
The presence of heavy metals, e.g. $\mathrm{Cu}$ in groundwater as a result of acid mine drainage (AMD) poses a threat to the environment. In order to remove cationic copper from solutions simulating the AMD, iron reactors were applied as zero-valent iron. The precipitates formed on the surface of the reactors and their specific surface area were determined. Affinity of copper in ionic form with reactors was investigated. The results show that for iron reactor immersed in solution of initial $\mathrm{pH} 3$, copper oxides as well as iron oxides and carbonates (to lower extent) were formed. More reaction products were generated in case of higher $\mathrm{pH}$ (initial $\mathrm{pH}=6$ ). These were mainly: copper and iron oxides, $\mathrm{Cu}^{0}$, and probably iron sulfates and carbonates. These precipitates caused an increase in specific surface of the reactors. In both cases (mainly for the reactor immersed in a solution of lower $\mathrm{pH}$ ) the surface of the reactors was not covered entirely with a coating. The sorption study indicated that copper ions may be retained on the surface of reactors only at higher $\mathrm{pH}$, because the $\mathrm{pH}$ at point of zero charge of iron reactors was ca. 6.2.
\end{abstract}

\section{INTRODUCTION}

In recent times, dumping sites resulting from the expansion of heavy industry create a significant problem for the environment in the Upper Silesia, Poland. At the end of the 20th century, ca. two hundred coal mine dumping sites existed. The leachate flowing from mine dumping sites may, among other things, contain copper in an ionic state and - as in most cases - may be characterized by low concentrations of dissolved oxygen, low $\mathrm{pH}(2-5)$, high total dissolved solids (TDS) values and high concentrations of sulfates.

Copper is one of the contaminants in concern due to its bioaccumulative effect and the level of toxicity. It can negatively affect biota, including humans, by causing liver and kidney damage resulting from long-term exposure [1]. Copper may appear in

${ }^{1}$ Faculty of Mining and Geology, Silesian University of Technology, ul. Akademicka 2, 44-100 Gliwice, Poland, e-mail: Tomasz.Suponik@polsl.pl 
groundwater as a result of acid mine drainage (AMD). AMD refers to the outflow of acidic water from mine dumping sites. The AMD effect arises as a result of the exposure of sulfide minerals, like pyrites, to atmospheric oxygen and water [2]. To protect the ground and surface water from acidic leachates containing sulfates and metal contaminants, a permeable reactive barrier (PRB) with zero-valent iron [3-9] or with sulfate-reducing bacteria [2] may be applied. In PRBs, contaminants are removed from the aquifer by flowing through a reactive barrier filled with a special material called the reactive material.

In order to remove copper in cationic form from the groundwater, zero-valent iron in the form of an iron reactor was applied in the tests described in this paper. The main aims of the paper were to assess the products created on the surface of the iron reactors as well as the specific surface areas of reactors and their affinity with copper in ionic form.

\section{EXPERIMENTAL}

The reactors used in the batch tests were made of steel ${ }^{2}$. The reactors were squareshaped, made of cold-rolled steel sheet $(0.5 \mathrm{~mm}$ thick), and their dimensions were $5 \times 5 \mathrm{~mm}$. Just before their use, the reactors were immersed in concentrated nitric acid for ca. $120 \mathrm{~s}$ and in demineralised water for ca. $120 \mathrm{~s}$. Immediately after, they were used in the batch tests. The tests were conducted in a programmable MULTI BIO RS-24 BIOSAN rotator equipped with plastic tubes filled with synthetic AMD solutions (so as to eliminate the headspace - a gaseous phase above the solutions; the volume of the solution amounted to $\left.58 \mathrm{~cm}^{3}\right)$ of the initial $\mathrm{pH}\left(\mathrm{pH}_{\mathrm{i}}\right)$ of 3.0 and 6.0 and with iron reactors - only one iron reactor was applied in each plastic tube. The $\mathrm{pHs}$ of the solutions were adjusted by slow titration with ultra-pure sulfuric acid solution $\left(0.1 \mathrm{~mol} / \mathrm{dm}^{3}\right)$ or with ultra-pure sodium hydroxide solution $\left(0.1 \mathrm{~mol} / \mathrm{dm}^{3}\right)$. Copper ion solutions were prepared by adding the desired amounts of metal salt $\left(\mathrm{CuSO}_{4} \cdot 5 \mathrm{H}_{2} \mathrm{O}\right)$ into bottles and pouring distilled water. The concentration of copper in the solutions amounted to $3.51 \mathrm{mg} / \mathrm{dm}^{3}\left(\mathrm{pH}_{\mathrm{i}}=3\right)$ and $2.96 \mathrm{mg} / \mathrm{dm}^{3}\left(\mathrm{pH}_{\mathrm{i}}=6\right)$. Karrabelli et al. [4] claimed that up to the $\mathrm{pH}$ of 6.5, copper exists in solution mainly in the form of $\mathrm{Cu}^{2+}$ ions. In the presented study, due to the value of $\mathrm{pH}$ in the research was lower than 6.5 , copper in the form of $\mathrm{Cu}^{2+}$ ions was present in all of the solutions.

Dissolved oxygen and $\mathrm{pH}$ have a significant impact on the fate of $\mathrm{Cu}$ in the groundwater [1]. The concentration of dissolved oxygen (DO) in groundwater (in an unconfined aquifer) located next to coal mine dumping sites in the south of Poland amounted

\footnotetext{
${ }^{2}$ In accordance with PN-EN 10131-2006 Polish Standard, Cold rolled uncoated and zinc or zinc-nickel electrolytically coated low carbon and high yield strength steel flat products for cold forming. Tolerances on dimensions and shape, Polish Committee for Standardization, Measurement and Quality.
} 
to ca. $6 \mathrm{mg} / \mathrm{dm}^{3}$ (based on own research). In order to reduce the concentration of oxygen in the samples of water and to adjust their condition to the condition of the contaminated aquifer, the solutions were heated before using them in the batch tests (to the temperature of $308 \mathrm{~K}$ ). This way, the initial concentration of DO amounted to ca. $6 \mathrm{mg} / \mathrm{dm}^{3}$. The ambient air temperature in the laboratory was ca. $295 \mathrm{~K}$.

After filling, the plastic tubes were sealed with corks. Each sample had to undergo 5 min orbital rotation in a programmable rotator (with a speed range of $20 \mathrm{rpm}$ ) after which, a $6 \mathrm{~s}$ reciprocal motion (with turning angle of $90^{\circ}$ ) with vibration motion followed. This sequence of shaking was repeatedly reiterated. The sequence continued for $24 \mathrm{~h}$ (after that time, a constant value was achieved). After shaking the samples, the iron reactors were pulled out and dried in an exsiccator. In order to identify the products formed on the surface of the reactors and their specific surface areas, and to determine their affinity with copper in an ionic form, the following research were conducted on iron reactors before and after the batch tests:

Identification of elements and determination of atomic concentration of solids located on the surface of iron reactors before the tests and formed after the batch tests. The measurements were carried out with the application of wavelength dispersive $\mathrm{X}$-ray spectroscopy/energy-dispersive X-ray spectroscopy and the use of a scanning electron microscope (SEM-WDS/EDS). This method allowed one to identify the elements (from beryllium to uranium) and calculate the atomic concentrations as well as to determine the correlation between the elements and their uniformity (on the basis of the maps of element distribution, the morphology of examined surface was conducted with the use of secondary electron imaging (SEI) mode). Measurements were performed using a JEOL JXA 8230 SuperProbe Electron Probe Microanalyzer. The device was equipped with an energy dispersive spectroscope (EDS) and three crystal spectrometers (measurement using wavelength dispersion (WDS)). The measurements (qualitative and quantitative analysis) were carried out as point analyses (focused beam from points marked in Figs. 1a, 2-4, the excitation area amounted to ca. $1 \mu \mathrm{m}$ ) and as average analysis of the layers (de-focused electron beam - beam scanning area ca. $500 \times 430 \mu \mathrm{m}$ ). The accelerating voltage was $15 \mathrm{keV}$.

Determination of the specific surface area of the iron reactors. The measurements were carried out with the use of Micromeritics Gemini 2360 Surface Area Analyzer. The device measured the surface area of two reactors immersed in two separate solutions of different $\mathrm{pH}$ and of one reactor which was not submerged in the solution. The instrument provided rapid and accurate sample analysis, including calculations of the following sample characteristics: single-point BET surface area, multi-point BET surface area, multipoint Langmuir surface area, total pore volume. The method applied a flowing-gas technique in which the analysis gas (nitrogen) flowed into a tube containing the iron reactor and into a balance tube at the same time. The principle of measurement consisted in the 
adsorption of nitrogen on the surface of the reactor at a constant temperature of liquid nitrogen $(77-78 \mathrm{~K})$. The internal volume and the temperature surrounding both tubes were maintained identical. The only difference was the pressure of the sample in the sample tube. The measurement range of the analyzer: specific surface from $0.01 \mathrm{~m}^{2} / \mathrm{g}$. In order to remove impurities and moisture, the reactors were dried at $383 \mathrm{~K}$ before measurements.

Determination of the affinity of $\mathrm{Cu}^{2+}$ ions with shells coating the iron reactor by measuring the $\mathrm{pH}$ at point of zero charge $\left(\mathrm{pH}_{P Z C}\right)$. The point of zero charge was obtained by the batch equilibrium method. This parameter describes the condition (value of $\mathrm{pH}$ ) in which the electrical charge on the surface of ZVI is zero. If the ZVI surface is positively charged with respect to the PZC (under acidic conditions or $\mathrm{pH}$ below $\mathrm{pH}$ PZC protons are sorbed on the functional group which results in a net positive charge the surface of reactor), the $\mathrm{Cu}^{2+}$ ions are not adsorbed on the ZVI surface. If the ZVI surface would be negatively charged in relation to the PZC (at values above the value of $\mathrm{pH}_{\mathrm{PZC}}$, the oxygen atoms stay deprotonized and the surface tends to have a net negative charge), the $\mathrm{Cu}^{2+}$ would be directly adsorbed on the ZVI surface. The tests were performed in the following way: iron reactors obtained from batch tests for the pHs of 3 and 6 were inserted into demineralised water for ca. $120 \mathrm{~s}$ and then shaken (separately) in plastic tubes, for $24 \mathrm{~h}$, with: (1) $58 \mathrm{~cm}^{3}$ of $0.01 \mathrm{~mol} / \mathrm{dm}^{3} \mathrm{KNO}_{3}$ solution, (2) $58 \mathrm{~cm}^{3}$ of $0.01 \mathrm{~mol} / \mathrm{dm}^{3} \mathrm{KNO}_{3}$ and $10^{-5} \mathrm{~mol} / \mathrm{dm}^{3} \mathrm{Cu}\left(\mathrm{NO}_{3}\right)_{2}$ solution, at various $\mathrm{pH}_{\mathrm{i}}$. The applied sequence of shaking was similar to the previous ones (i.e. for AMD solutions). The initial $\mathrm{pHs}$ of the solutions were adjusted by slow titration with ultra-pure potassium hydroxide solution $\left(0.1 \mathrm{~mol} / \mathrm{dm}^{3}\right)$ or with ultra-pure nitric acid solution $\left(0.1 \mathrm{~mol} / \mathrm{dm}^{3}\right)$. The amount of $\mathrm{H}^{+}$or $\mathrm{OH}^{-}$ions adsorbed on the shell of iron reactors was calculated from the difference between the initial and the final concentrations of $\mathrm{H}^{+}$or $\mathrm{OH}^{-}$ions [10]. $\mathrm{pH}$ was measured with the use of Knick PORTAMESS 913 meter and the SenTix 41 electrode.

\section{RESULTS AND DISCUSSION}

Figure 1 presents the electron images that illustrate the surface morphology of iron reactors before the tests and after the batch tests for initial $\mathrm{pH}_{\mathrm{i}}$ of 3 and 6 . Based on the figure and upon visual inspection of reactors, it may be confirmed that more chemical compounds were formed on the surface of the iron reactor in the case of the higher initial $\mathrm{pH}$ of the solution. The qualitative and quantitative measurement performed as average analysis (surface areas were $500 \times 430 \mu \mathrm{m}$ ) and as point analyses (the analyzed points are shown in Fig. 1a for the reactor before the tests and in Figs. 2 and 3 for the reactor after the tests for $\mathrm{pH}_{\mathrm{i}}=3$. Figure 4 presents the analyzed points for the reactor after the tests for $\mathrm{pH}_{\mathrm{i}}=6$ ) are presented in Table 1 . 

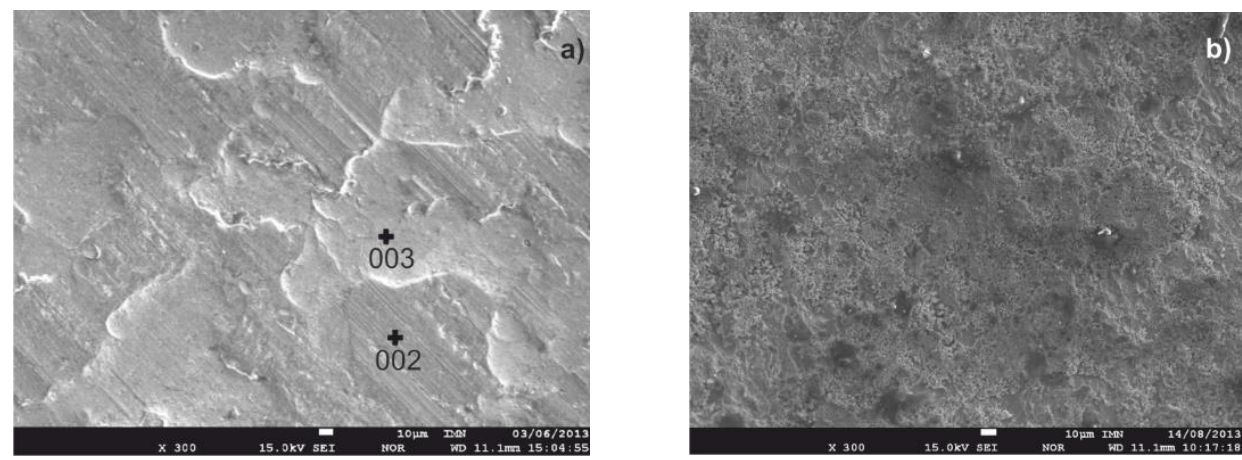

Fig. 1. SEM images for the iron reactor before (a) and after the batch test, $\mathrm{pH}_{\mathrm{i}}=3(\mathrm{~b})$ and, $\mathrm{pH}_{\mathrm{i}}=6(\mathrm{c})$; (magnification 300×)

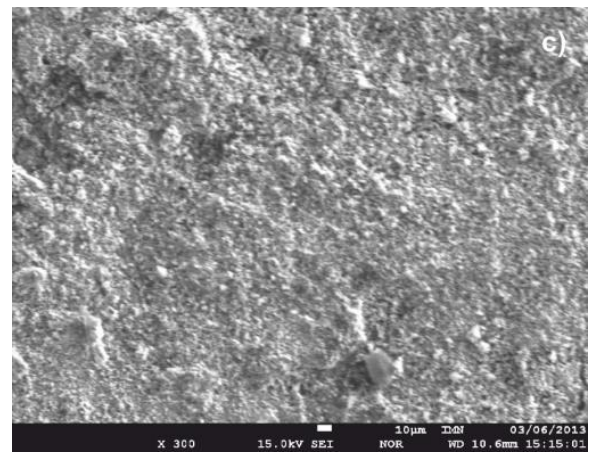

Each assessed sample contained carbon and oxygen. The presence of these elements has been explained by both contamination of the samples in their transport for the measurement (atomic concentration of oxygen and carbon varied and reached 40.99 and $34.53 \%$ respectively (Table 1 ) and by natural processes occurring in the solutions. Oxygen could occur from water as a result of the production of iron corrosion products, while steel contains small amounts of carbon. These results have not been taken into consideration in further analysis, except for carbon and the oxygen contained in carbonates and the oxygen contained in metal oxides. The elements found in the reactor which was not immersed in the solution (Table 1) are typically contained in steel (mainly iron). Chromium and manganese are common steel admixtures. The content of silicon is also at normal level. Silicon is used for the deoxidation of steel during production.

In order to evaluate acidity of the solution effective for copper precipitation, , only iron and copper were taken into account in the following subparagraph. The atomic concentrations (average analysis) of iron and copper on iron reactors for the initial $\mathrm{pH}_{\mathrm{i}}$ equal to 3 and 6 amounted to $62.40 \%$ and $54.45 \%$ for iron and $37.60 \%$ and $45.55 \%$ for copper, respectively. This means that copper was removed more effectively from the solution at a higher $\mathrm{pH}$.

Maps of elements distribution for iron reactor immersed in solution of $\mathrm{pH}_{\mathrm{i}}=3$ show three groups of compounds. These are: copper compounds and iron compounds, and calcium and iron carbonates. 

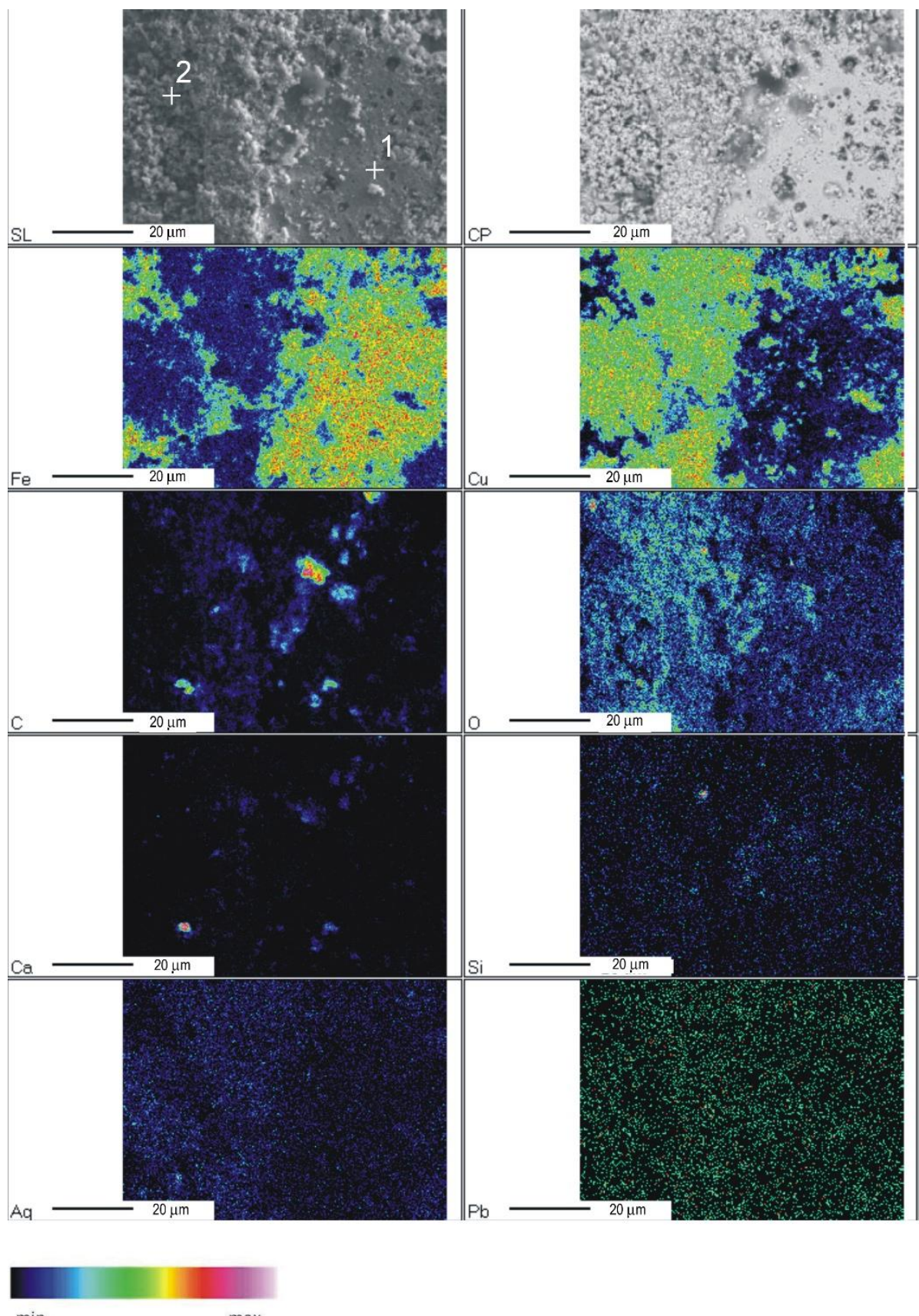

$\min$.

$\max$

Fig. 2. Elemental WDS mapping images obtained from the iron reactor immersed in the solution of $\mathrm{pH}_{\mathrm{i}}=3$ (magnification $1500 \times$ ) 

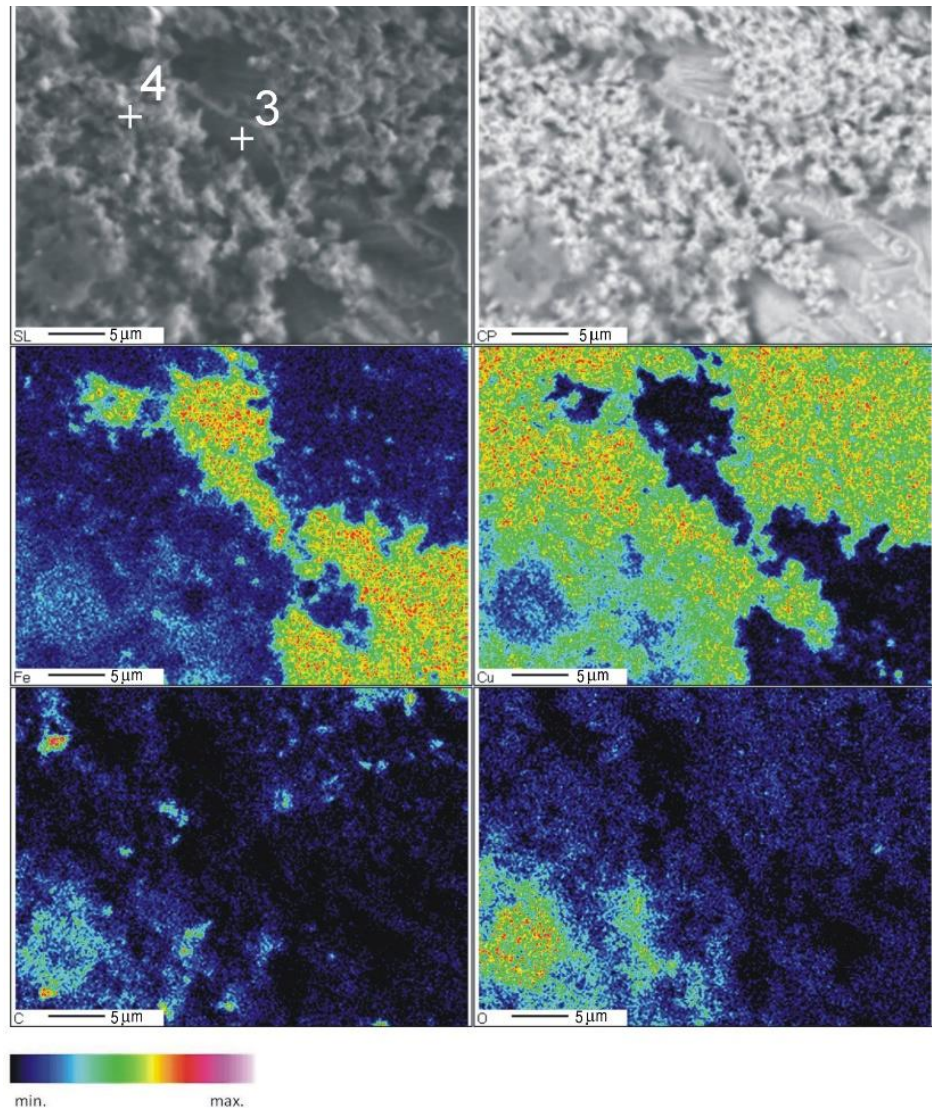

Fig. 3. Elemental WDS mapping images obtained from the iron reactor immersed in the solution of $\mathrm{pH}_{\mathrm{i}}=3$ (magnification $3000 \times$ )

Iron compounds mainly in the form of thin layers of $\mathrm{Fe}-\mathrm{O}$ corrosion products are visible on the right side of the map shown in Fig. 2. These compounds are also present in Fig. 3, in the lower right part of the map and in the upper middle part. In accordance with Table 1, the atomic concentrations of $\mathrm{Fe}, \mathrm{O}, \mathrm{C}$ and $\mathrm{Cu}$ in points 1 and 3 located in these spots amounted to $90.22,2.37,3.52,3.81 \%$ and $88.94,2.60,1.68,6.67 \%$, respectively. This may indicate that iron occurs also in metallic form. In these places reactor probably was not fully covered with precipitates.

Copper compounds are located mainly on the left part of the maps presented in Fig. 2 and in the upper right and left parts of the maps in Fig. 3. In these places, oxygen maps shown in Figs. 2 and 3 indicate higher concentrations of oxygen than in the areas where iron predominates. Hence, it can be said that these compounds are predominantly oxides of copper. Small spots of carbon have also been noticed in the precipitates covering the iron reactor. The carbon is bonded with oxygen, creating carbonate bonded 
with calcium or iron, or with iron only, thus creating pearlite - the main component of steel. The presence of calcium and carbonates could be explained by improperly distilled water.

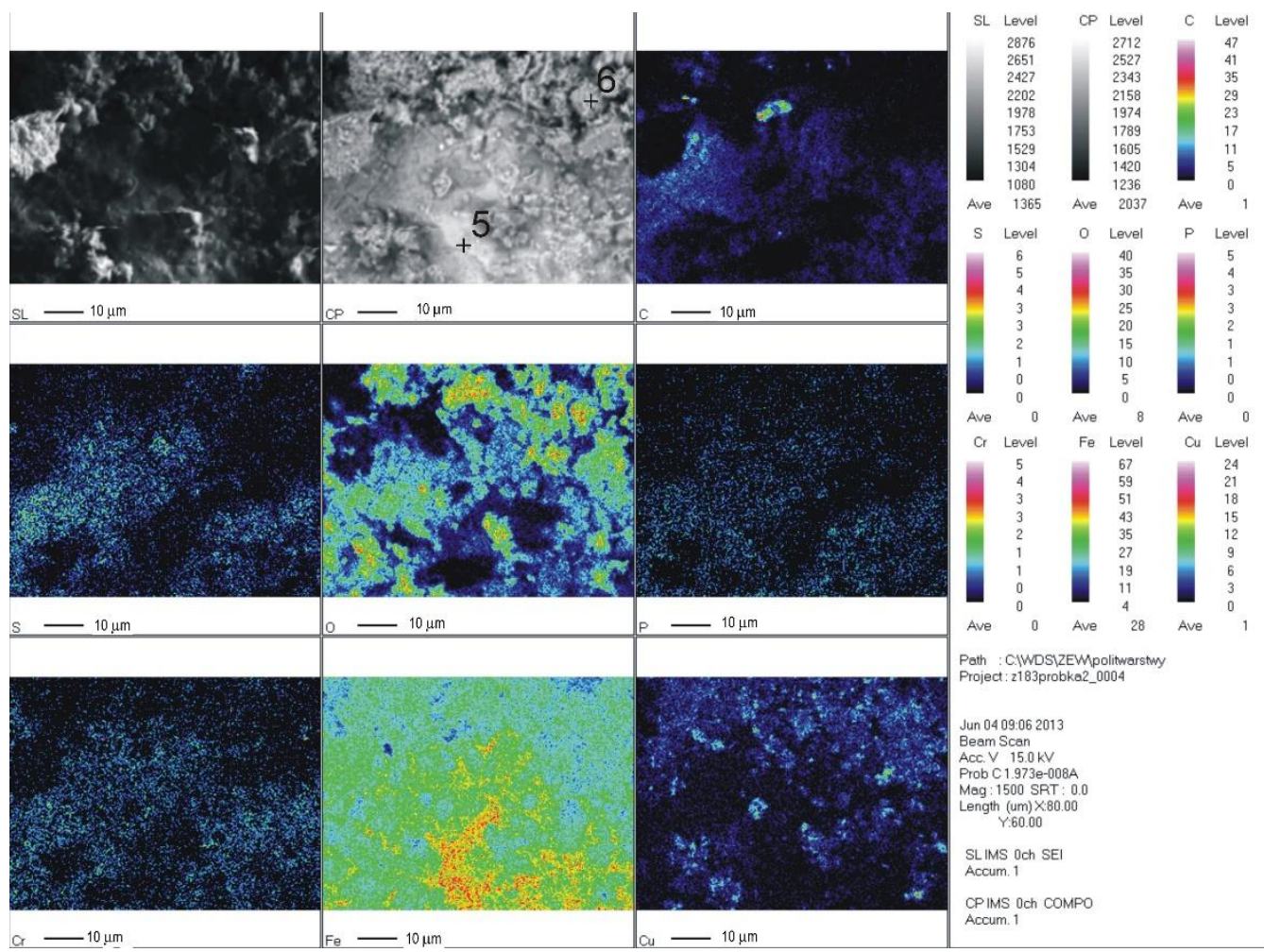

Fig. 4. Elemental WDS mapping images obtained from the iron reactor immersed in the solution of $\mathrm{pH}_{\mathrm{i}}=6$, (magnification $1500 \times$ )

The composition of the compound formed on the iron reactor in the solution of $\mathrm{pH}_{\mathrm{i}}=6$ is more complex, as more compounds have been formed (Fig. 4). In this case, five areas can be distinguished. Iron, probably in the form of thin layers of Fe-O corrosion products and in metallic form (where the oxygen concentration is close to zero) may be found in the bottom centre of the images of the Fig. 4. Due to the very low concentration of oxygen in the upper left part of the image of Fig. 4, it can be concluded that copper and iron in metallic form can also be found at this location. At the same time, copper and iron oxides have formed in the upper (right) part of the maps presented in the Fig. 4 (see also Table 1, values for point 6 in Fig. 4). As shown in the lower right corner of the images, $\mathrm{Fe}, \mathrm{O}, \mathrm{S}$ and $\mathrm{Cu}$ are present and - as a result of the purification of the AMD solution - likely forming iron sulfate, iron oxide and copper oxides. In the middle-left part, on the other hand, the concentrations of $\mathrm{C}, \mathrm{S}, \mathrm{O}$ and $\mathrm{Fe}, \mathrm{Cu}$ are higher 
thus probably forming iron and copper oxides, carbonates and sulfates. Still, there is one carbon spot in Fig. 4, which has not been mentioned so far. It is probably the pearlite, which is located in the top centre of the images. The presence of sulfates on the surface of the reactor is caused by the preparation process of the AMD solution.

Table 1

Atomic concentrations of elements (expressed as percentages) on the iron reactors before and after the batch tests

\begin{tabular}{|c|c|c|c|c|c|c|c|c|c|c|c|}
\hline \multirow{6}{*}{ Element } & \multicolumn{11}{|c|}{ Stage of the batch test ${ }^{\mathrm{a}}$} \\
\hline & \multirow{2}{*}{\multicolumn{3}{|c|}{ Before the batch tests }} & \multicolumn{8}{|c|}{ After $24 \mathrm{~h}$ of shaking } \\
\hline & & & & \multicolumn{5}{|c|}{$\mathrm{pH}_{\mathrm{i}}=3$} & \multicolumn{3}{|c|}{$\mathrm{pH}_{\mathrm{i}}=6$} \\
\hline & \multirow{3}{*}{ A } & \multicolumn{2}{|c|}{$\mathrm{P}$} & \multirow{3}{*}{ A } & \multicolumn{4}{|c|}{ Point } & \multirow{3}{*}{ A } & \multicolumn{2}{|c|}{$\mathrm{P}$} \\
\hline & & 002 & 003 & & 1 & 2 & 3 & 4 & & 5 & 6 \\
\hline & & \multicolumn{2}{|c|}{ (Fig. 1a) } & & \multicolumn{2}{|c|}{ (Fig. 2) } & \multicolumn{2}{|c|}{ (Fig. 3) } & & \multicolumn{2}{|c|}{ (Fig. 4) } \\
\hline $\mathrm{Ag}$ & & & & 0.13 & & 0.30 & 0.03 & 0.30 & & & 0.41 \\
\hline $\mathrm{Al}$ & & & & & 0.04 & 0.02 & 0.04 & 0.04 & & 0.02 & 0.03 \\
\hline $\mathrm{C}$ & 15.85 & 34.53 & 19.62 & 29.73 & 3.52 & 9.76 & 1.68 & 5.93 & 14.01 & 5.04 & 4.82 \\
\hline $\mathrm{Ca}$ & & & & 0.28 & & 0.01 & & 0.05 & 0.12 & 0.08 & 0.87 \\
\hline $\mathrm{Cr}$ & 0.06 & 0.09 & & & & & & & 0.04 & & \\
\hline $\mathrm{Cu}$ & & & & 22.25 & 3.81 & 65.51 & 6.67 & 72.20 & 20.49 & 9.24 & 15.83 \\
\hline $\mathrm{Fe}$ & 79.83 & 49.76 & 75.12 & 36.93 & 90.22 & 11.71 & 88.94 & 12.64 & 24.49 & 78.24 & 27.91 \\
\hline $\mathrm{Mn}$ & 0.43 & 0.16 & 0.25 & & & & & & & & \\
\hline $\mathrm{O}$ & 3.55 & 15.08 & 4.76 & 10.55 & 2.37 & 12.62 & 2.60 & 8.71 & 40.99 & 7.24 & 49.24 \\
\hline $\mathrm{P}$ & & & & & & & & & 0.31 & & \\
\hline $\mathrm{Pb}$ & & & & 0.03 & 0.01 & 0.05 & 0.01 & 0.07 & & 0.01 & 0.08 \\
\hline$S$ & & & & & 0.02 & 0.03 & & 0.07 & 0.42 & 0.12 & 0.51 \\
\hline $\mathrm{Si}$ & 0.27 & 0.37 & 0.24 & 0.11 & & & 0.02 & 0.02 & 0.14 & 0.02 & 0.31 \\
\hline
\end{tabular}

$\mathrm{pH}_{\mathrm{i}}-$ initial $\mathrm{pH}$ of the solution, $\mathrm{A}$ - average analysis (one measurement), $\mathrm{P}$ - point analysis.

$\mathrm{Li}$ and Zhang [5] report that ions with the standard electrode potential higher than that of $\mathrm{Fe}^{2+}$ are bound to zero-valent iron as a result of redox reaction. The value of standard electrode potential for $\mathrm{Cu}^{2+}$ is higher than that of $\mathrm{Fe}^{2+}$ and the following reaction proceeds:

$$
\mathrm{Fe}^{0}+\mathrm{Cu}^{2+} \rightarrow \mathrm{Fe}^{2+}+\mathrm{Cu}^{0}
$$

Rangsivek and Jekel [6] and Uzum et al. [11] claim that in the case of deoxygenated acidic conditions in water and for nano-scale zero-valent iron in the presence of kaolinite clay, $\mathrm{Cu}^{0}$ and $\mathrm{Cu}_{2} \mathrm{O}$ are formed on the surface of iron. In their studies, Karabelli et al. [4] confirmed these results for pure nano zero-valent iron and claimed that $\mathrm{Cu}^{2+}$ ions were removed primarily via a redox mechanism which resulted in the formation of $\mathrm{Cu}_{2} \mathrm{O}$ and $\mathrm{Cu}^{0}$. The redox reaction for the formation of $\mathrm{Cu}_{2} \mathrm{O}$ might then be as follows [4]: 


$$
\mathrm{Fe}^{0}+2 \mathrm{Cu}^{2+}+\mathrm{H}_{2} \mathrm{O} \rightarrow \mathrm{Fe}^{2+}+\mathrm{Cu}_{2} \mathrm{O}+2 \mathrm{H}^{+}
$$

The results of the research conducted by the SEM-WDS/EDS method confirmed the possibility of the formation of copper oxides for both analyzed $\mathrm{pHs}$ and the probable formation of $\mathrm{Cu}^{0}$ only for one area of the analyzed reactor, for the initial $\mathrm{pH}$ of 6.0.

As provided by Furukawa et al. [12], Roh et al. [13], Rangsivek and Jekel [6] and Uzum et al. [11], the secondary minerals typically formed on the surface of ZVI as a result of the purification of groundwater contaminated with metal ions are magnetite $\left(\mathrm{Fe}_{3} \mathrm{O}_{4}\right)$, aragonite $\left(\mathrm{CaCO}_{3}\right)$, calcite $\left(\mathrm{CaCO}_{3}\right)$, hematite $\left(\alpha-\mathrm{Fe}_{2} \mathrm{O}_{3}\right)$, goethite $(\alpha-\mathrm{FeOOH})$, lepidocrocite $(\gamma-\mathrm{FeOOH})$, ferrous hydroxide $\mathrm{Fe}(\mathrm{OH})_{2}$, ferrihydrite $\left(\mathrm{Fe}_{2} \mathrm{O}_{3} \cdot 0.5 \mathrm{H}_{2} \mathrm{O}\right)$, siderite $\left(\mathrm{FeCO}_{3}\right)$, ferrous sulfide $\left(\mathrm{FeS}_{2}\right)$, greigite $\left(\mathrm{Fe}_{3} \mathrm{~S}_{4}\right)$, mackinawite $\left((\mathrm{FeNi})_{1+x} \mathrm{~S}\right.$, where $x$ ranges from 0 to 0.11$)$, and green rust $\left(\left[\mathrm{Fe}_{1-x}^{2+} \mathrm{Fe}_{x}^{3+}(\mathrm{OH})_{2}\right]^{x+}\left[(x / n) \mathrm{A}^{n-} \cdot m \mathrm{H}_{2} \mathrm{O}\right]^{x-}\right.$, where $x$ is the $\mathrm{Fe}^{3+} / \mathrm{Fe}_{\text {tot }}$ ratio), which is usually created under neutral conditions. Although, according to Wilkin and McNeil [7], green rust is a primary corrosion product formed on ZVI in sulfate rich solutions, it has not been observed (by visual inspection) on the surface of the iron reactors. In accordance with the research conducted with the use of SEM-EDS/WDS, the rest of the compounds presented above, mainly iron oxides, may have formed on the surface of both reactors (especially on the reactor immersed in a solution of $\mathrm{pH}_{\mathrm{i}}=6$ ).

Based on the results obtained from the SEM-WDS/EDS measurements, it cannot be determined precisely which of these compounds have been formed on the surface of the iron reactors. In order to verify these products and to assess the mechanisms of water purification using zero-valent iron, X-ray diffraction (XRD) and X-ray photoelectron spectroscopy (XPS) measurements should be taken before and after the batch tests.

The values of specific surface areas obtained by means of the multi-point and singlepoint BET as well as by multi-point Langmuir (relative pressures of 0.0506 and 0.3043 ) methods for $\mathrm{pH}_{\mathrm{i}}=3$ amounted to: $0.1206,0.1428$ and $0.2084 \mathrm{~m}^{2} / \mathrm{g}$, respectively, while for the initial $\mathrm{pH}=6$ these equalled: $0.3354,0.3434$ and $0.4893 \mathrm{~m}^{2} / \mathrm{g}$. For the iron reactor before the tests, the same parameters amounted to $0.0312,0.0370$ and $0.0393 \mathrm{~m}^{2} / \mathrm{g}$, meaning that large amounts of chemical compounds have formed on the surface of the iron reactors after the tests, especially for higher $\mathrm{pH}$ values. The total pore volumes of the iron reactors before and after the batch tests for $\mathrm{pH}_{\mathrm{i}}$ of 3 and 6 , were $0.059,0.078$ and $0.118 \mathrm{~cm}^{3} / \mathrm{g}$, respectively, which confirmed the above observation.

Figure 5 presents the results of the tests conducted for the determination of $\mathrm{pH}_{\mathrm{PZC}}$. $\mathrm{pH}$ at the point of zero charge, determined by the batch equilibrium method, for both iron reactors (i.e. for reactors which have been used in AMD solution for the $\mathrm{pH}_{\mathrm{i}}$ of 3 and 6) shaken in a $0.01 \mathrm{~mol} / \mathrm{dm}^{3} \mathrm{KNO}_{3}$ solutions, amounted to $7\left(\mathrm{pH}_{\mathrm{f}}\right.$ level at which common plateau is reached, see dashed arrow in Fig. 5). This leads to the conclusion that $\mathrm{pH}_{\mathrm{PZC}}$ is independent of the initial $\mathrm{pH}$ of AMD solutions. In the presence of copper ions (i.e. for the $0.01 \mathrm{~mol} / \mathrm{dm}^{3} \mathrm{KNO}_{3}+10^{-5} \mathrm{~mol} / \mathrm{dm}^{3} \mathrm{Cu}\left(\mathrm{NO}_{3}\right)_{2}$ ) solution, $\mathrm{pH}_{\mathrm{pzc}}$ decreases to the value of ca. $6.2\left(\mathrm{pH}_{\mathrm{f}}\right.$ at which common plateau is reached, see continuous 
arrow in Fig. 5) in the case of both iron reactors, due to specific adsorption of these ions. This stands in agreement with the literature data on the influence of specific adsorption of counter ions on $\mathrm{pH}_{\mathrm{PZC}}$ (specific adsorption of cations shifts $\mathrm{pH}_{\mathrm{PZC}}$ toward lower $\mathrm{pH}$ values).

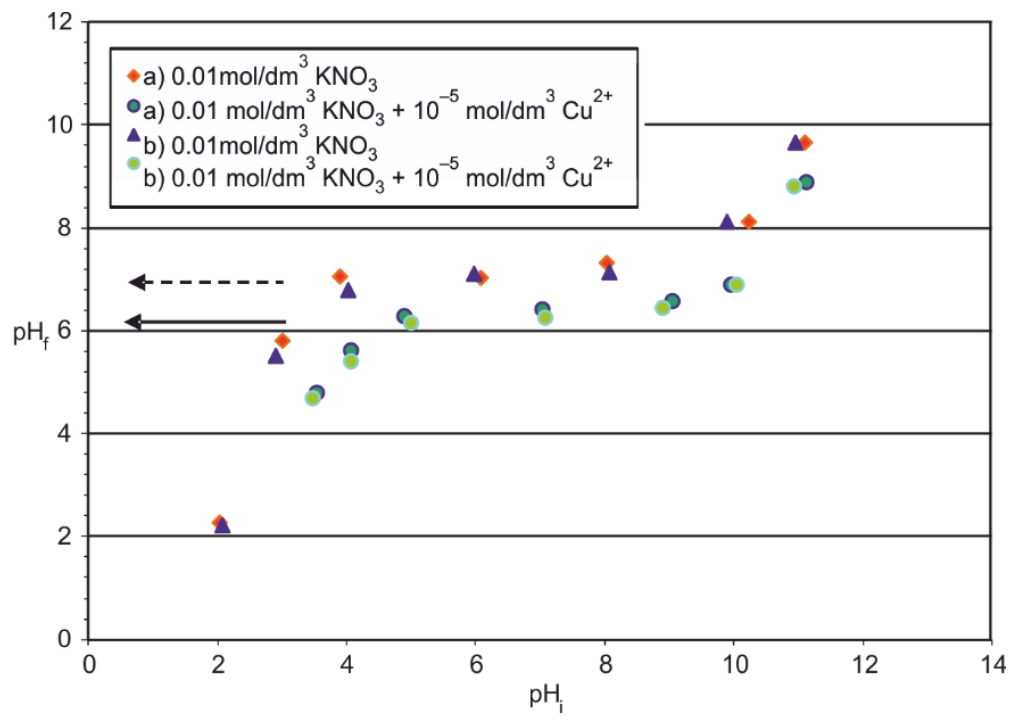

Fig. 5. The final value of $\mathrm{pH}\left(\mathrm{pH}_{\mathrm{f}}\right)$ vs. its initial value $\left(\mathrm{pH}_{\mathrm{i}}\right)$ for iron reactors immersed (separately) in two solutions: $0.01 \mathrm{~mol} / \mathrm{dm}^{3} \mathrm{KNO}_{3}$ and $0.01 \mathrm{~mol} / \mathrm{dm}^{3} \mathrm{KNO}_{3}+10^{-5} \mathrm{~mol} / \mathrm{dm}^{3} \mathrm{Cu}\left(\mathrm{NO}_{3}\right)_{2}$. Two reactors were used in each solution: a) the one that was shaken in an AMD solution for initial $\mathrm{pH}=3, \mathrm{~b}$ ) the one that was shaken in an AMD solution for the initial $\mathrm{pH}=6$

The point of zero charge for most iron oxides (hydroxide) is typically in the range of $\mathrm{pH}$ from around 6 to 8 (e.g. 7.8 for lepidocrocite $\gamma-\mathrm{FeOOH}, 6.1-7.5$ for maghemite $\gamma-\mathrm{Fe}_{2} \mathrm{O}_{3}, 5.5-9.3$ for hematite $\alpha-\mathrm{Fe}_{2} \mathrm{O}_{3}, 3.8-8.2$ for magnetite, $6.2-9.6$ for goethite $\alpha-\mathrm{FeOOH}, 6.0-6.5$ for iron(II) hydroxide [14], while for $\mathrm{CuO}$ it amounts to 6.9-7.6 [15]). For calcite $\left(\mathrm{CaCO}_{3}\right)$ and siderite $\left(\mathrm{FeCO}_{3}\right)$ the point of zero charge, in turn, equals respectively 7.3 [16] and 6 [17]. The above data confirms the results obtained in the tests.

Based on the above, it can be claimed that the sorption of $\mathrm{Cu}^{2+}$ on the surface of reactors is not possible in the first case (for the solution of the initial $\mathrm{pH}$ of 3 for which the final $\mathrm{pH}$ was 4.82), while it may occur in the second case - in the experiment in which the initial $\mathrm{pH}$ of the AMD solution amounted to 6.00 and the final $\mathrm{pH}$ was 6.39 . The shells coating the reactor following the test were characterized by approximately equal amounts of negative and positive charges, as the $\mathrm{pH}$ of the solution (6.39) is close to the pzc of the compounds formed on the surface of the ZVI. Since both charges exist in the shells coating the reactor at this $\mathrm{pH}$, the sorption of $\mathrm{Cu}^{2+}$, as well as the negatively charged ions which were present in the solution, can occur on the reactor surface. 


\section{CONCLUSIONS}

The outflow of acidic water from mine waste dumps may cause pollution of both surface and ground water. The application of zero-valent iron in the form of an iron reactor for removing copper in cationic form from two solutions (of $\mathrm{pH}$ equal to 3 and 6) simulating acid mine drainage (AMD) has been investigated.

In the case of $\mathrm{pH}_{\mathrm{i}}=6$, higher amounts of precipitates formed on the iron reactor creating its larger specific surface area. It was confirmed that copper ions may be removed from water by adsorption only at higher $\mathrm{pH}$.

The qualitative and quantitative analyses, as well as the correlation between the elements and their uniformity, have shown that in solutions of higher $\mathrm{pH}$ copper and iron oxides, $\mathrm{Cu}^{0}$ as well as iron sulfates and carbonates formed on the surface of the reactor, while at lower $\mathrm{pH}$ only copper oxides, iron oxides and carbonates formed. Thus, the removal of copper from water with a lower $\mathrm{pH}$ is less effective and leads mainly to the formation of copper oxides on the surface of zero-valent iron.

\section{REFERENCES}

[1] Moore L.R., Durand J.R., Copper removal from mine effluents. From lab to field evaluations, Mine Water Environ., 2013, 32, 239.

[2] Zhang M., WANG H., Simultaneous removal of copper, zinc, and sulfate from coal mine waste in a laboratory SRB bioreactor using lactate or ethanol as carbon sources, Mine Water Environ., 2013, 32, 314.

[3] Аyob A., Ismail N., Teng T.T., Abdullah A.Z., Immobilization of $\mathrm{Cu}^{2+}$ using stabilized nano zero valent iron particles in contaminated aqueous, Environ. Prot. Eng., 2012, 38 (3), 119.

[4] Karabelli D., Uzum C., Shahwan T., Eroglu A.E., Scott T.B., Hallam K.R., Lieberwirth I., Batch removal of aqueous $\mathrm{Cu}^{2+}$ ions using nanoparticles of zero-valent iron. A study of the capacity and mechanisms of uptake, Ind. Eng. Chem. Res., 2008, 47, 4758.

[5] Li X.Q., ZHANG W.X., Sequestration of metal cations with zerovalent iron nanoparticles. A study with high resolution X-ray photoelectron spectroscopy (HRXPS), J. Phys. Chem., 2007, 111 (19), 6939.

[6] RANgSiveK R., JeKel M.R., Removal of dissolved metals by zero-valent iron (ZVI). Kinetics, equilibria, processes and implications for stormwater runoff treatment, Water Res., 2005, 39, 4153.

[7] WILKIN R.T., MCNEIL M.S., Laboratory evaluation of zero-valent iron to treat water impacted by acid mine drainage, Chemosphere, 2003, 53, 715.

[8] SUPONIK T., Groundwater treatment with the use of zero-valent iron in the permeable reactive barrier technology, Physicochem. Probl. Mineral Proc., 2013, 49 (1), 13.

[9] SUPONIK T., Zero-valent iron for inorganic contaminants removal from low $\mathrm{pH}$ water, Environ. Prot. Eng., 2015, 41 (1), 15.

[10] Babić B.M., Milonjić S.K., Polovina M.J., Kaludierović B.V., Point of zero charge and intrinsic equilibrium constants of activated carbon cloth, Carbon, 1999, 37, 477.

[11] Uzum C., Shahwan T., ERoglu A.E., Hallam K.R., Scott T.B., LieberwiRTh I., Synthesis and characterization of kaolinite-supported zero-valent iron nanoparticles and their application for the removal of aqueous $\mathrm{Cu}^{2+}$ and $\mathrm{Co}^{2+}$ ions, Appl. Clay Sci., 2009, 43, 172. 
[12] FuRUKAWA Y., KIM J.W., Watkins J., WiLkin R.T., Formation of ferrihydrite and associated iron corrosion products in permeable reactive barriers of zero-valent iron, Environ. Sci. Technol., 2002, 36 (24), 5469.

[13] RoH Y., LEE S.Y., ElLESS M.P., Characterization of corrosion products in the permeable reactive barriers, Environ. Geol., 2000, 40, 184.

[14] Kosmulski M., The pH-dependent surface charging and points of zero charge. V. Update, J. Colloid. Interface Sci., 2011, 353 (1), 1.

[15] GonZalez G., LASKOWSKI J., The point of zero charge of oxidized copper minerals: tenorite, malachite and chrysocolla, J. Electroanal. Chem., 1974, 53 (3), 452.

[16] Sondi I., BISCAN J., VDOvic N., SKAPIN S.D., The electrokinetic properties of carbonates in aqueous media revisited, Colloids Surf. A, 2009, 342 (1), 84.

[17] Foss M., GulbrandSEn E., SJoblom J., Adsorption of corrosion inhibitors onto iron carbonate ( $\left.\mathrm{FeCO}_{3}\right)$ studied by zeta potential measurements, J. Dispersion Sci. Technol., 2010, 31 (2), 200. 